\title{
Article
}

\section{The Effects of Cold Atmospheric Pressure Plasma on Germination Parameters, Enzyme Activities and Induction of DNA Damage in Barley}

\author{
Mária Pet'ková ${ }^{1}$, Renáta Švubová ${ }^{2}{ }^{\circledR}$, Stanislav Kyzek ${ }^{1, *}$, Veronika Medvecká ${ }^{3}{ }^{\circledR}$, L'udmila Slováková ${ }^{2}$, \\ Andrea Ševčovičová ${ }^{1}\left(\mathbb{D}\right.$ and Eliška Gálová ${ }^{1}$
}

1 Department of Genetics, Faculty of Natural Sciences, Comenius University, Ilkovičova 6, Mlynská Dolina, 84215 Bratislava, Slovakia; petkova21@uniba.sk (M.P.); andrea.sevcovicova@uniba.sk (A.Š.); eliska.galova@uniba.sk (E.G.)

2 Department of Plant Physiology, Faculty of Natural Sciences, Comenius University, Ilkovičova 6, Mlynská Dolina, 84215 Bratislava, Slovakia; renata.svubova@uniba.sk (R.Š.); ludmila.slovakova@uniba.sk (L'.S.)

3 Department of Experimental Physics, Faculty of Mathematics, Physics and Informatics, Comenius University, Mlynská Dolina, 84248 Bratislava, Slovakia; medvecka3@uniba.sk

* Correspondence: kyzek2@uniba.sk

check for updates

Citation: Pet'ková, M.; Švubová, R.; Kyzek, S.; Medvecká, V.; Slováková, L'; Ševčovičová, A.; Gálová, E. The Effects of Cold Atmospheric Pressure Plasma on Germination Parameters, Enzyme Activities and Induction of DNA Damage in Barley. Int. J. Mol. Sci. 2021, 22, 2833. https://doi.org/ ijms22062833

Academic Editor: Ricardo Molina

Received: 5 February 2021

Accepted: 8 March 2021

Published: 11 March 2021

Publisher's Note: MDPI stays neutral with regard to jurisdictional claims in published maps and institutional affiliations.

Copyright: (C) 2021 by the authors Licensee MDPI, Basel, Switzerland. This article is an open access article distributed under the terms and conditions of the Creative Commons Attribution (CC BY) license (https:// creativecommons.org/licenses/by/ $4.0 /)$

\begin{abstract}
Climate change, environmental pollution and pathogen resistance to available chemical agents are part of the problems that the food industry has to face in order to ensure healthy food for people and livestock. One of the promising solutions to these problems is the use of cold atmospheric pressure plasma (CAPP). Plasma is suitable for efficient surface decontamination of seeds and food products, germination enhancement and obtaining higher yields in agricultural production. However, the plasma effects vary due to plasma source, treatment conditions and seed type. In our study, we tried to find the proper conditions for treatment of barley grains by diffuse coplanar surface barrier discharge, in which positive effects of CAPP, such as enhanced germination or decontamination effects, would be maximized and harmful effects, such as oxidation and genotoxic potential, minimized. Besides germination parameters, we evaluated DNA damage and activities of various germination and antioxidant enzymes in barley seedlings. Plasma exposure resulted in changes in germination parameters and enzyme activities. Longer exposures had also genotoxic effects. As such, our findings indicate that appropriate plasma exposure conditions need to be carefully optimized in order to preserve germination, oxidation balance and genome stability, should CAPP be used in agricultural practice.
\end{abstract}

Keywords: barley; cold atmospheric pressure plasma; DNA damage; enzyme activities; germination parameters; oxidative stress

\section{Introduction}

Cold atmospheric pressure plasma (CAPP) is relatively widely used in agriculture and food production for the treatment of plants and seeds and also as a more environmentally friendly way for water desalination or decontamination [1-3] and for remediation [4,5]. Recent studies about CAPP effects are focused not just on water purification but also on plasma application on plants as a possible ecological solution for increasing food production. Climate change, environmental pollution and increasing pathogen resistance to available chemical agents represent some of the problems that the food industry has to face in order to ensure healthy food for people and livestock. One of the promising solutions to these problems is the use of CAPP. A number of available plasma sources and relatively simple treatment allow plasma to be applied to many agricultural products in postharvest or/and preharvest ways. Preharvest application primarily includes seed treatment in order to improve germination $[6,7]$ and postharvest application includes treatment of final agricultural products such as fruits [8,9] or nuts [10-13], mainly for 
surface decontamination. In postharvest treatment, not only are decontamination effects of plasma important, but also physiological and morphological properties such as taste or color should be maintained.

There are many positive aspects of preharvest plasma treatment, e.g., surface decontamination [6,14], germination improvement [6,15], faster growth [13] and associated positive physiological and biochemical properties' enhancement [16]. These effects were also observed on many different seeds treated with plasma generated by the same plasma source as in this study [16,17]. Active plasma compounds, including UV light or reactive oxygen and nitrogen species (RONS), are probably responsible for the positive effects of plasma. Through low levels of oxidative stress, plasma can eliminate pathogens presented on the surface of seeds [18] and it is impossible to develop resistance to plasma treatment as it causes serious damage in pathogen cells [19]. At the same time, plasma can change the intracellular concentration of RONS, which, as signal molecules, are able to modulate seed germination signal pathways [20,21].

Plasma treatment efficiency is variable and can change according to the plasma source, working gas, treated seed type and morphology of their surface [18], and for these reasons, it is almost impossible to determine general plasma treatment conditions for different seeds. The optimal plasma treatment time is specific for each seed species, as was observed in several studies $[6,22,23]$, and probably depends on the type of seed, its size, surface hardness, embryo location, etc. However, Hthis is not the only problem with plasma treatment. Sometimes, the exposure time necessary for pathogen inactivation is too long and also causes damage to seeds, resulting in lower germination, as was shown in previous studies $[24,25]$. It was shown that longer exposure of seeds to plasma can cause serious damage to seed morphology that leads to reduced germination.

The aim of the present study was to identify treatment conditions for barley grains (Hordeum vulgare L.) by CAPP generated in different gases (ambient air, nitrogen and oxygen), causing no harmful effects and, at the same time, maintaining the positive ones (such as increased germination). Since the main active plasma components are RONS, our attention was focused on indirect oxidative stress markers, namely superoxide dismutase (SOD) and guaiacol peroxidase (G-POX), which detoxify oxidative stress products from cells. Determining the amount of DNA breaks and the presence of oxidized bases in DNA were also used as indirect evidence of oxidative stress induced by CAPP.

\section{Results}

\subsection{Germination Parameters}

In the case of cereal as barley, which has almost $100 \%$ germination (Figure 1) and retains it for many years, when stored correctly (in the dark, at a temperature of $8{ }^{\circ} \mathrm{C}$ ), the use of cold atmospheric pressure plasma pre-sowing technology is important in the decontamination of grain surfaces from pathogenic microflora, faster recovery of metabolic activity in grains (lytic enzyme activation), faster growth and development of young seedlings and yield increase. Our results show that the CAPP treatment of barley grains had a negative effect on germination (\%), germination potential (\%), germination index (\%) and grain vigor index (\%) with increasing plasma application dose. The vigor of the grains did not decrease as dramatically as the germination potential and germination index. In the case of $10 \mathrm{~s}$ plasma application (for all working gases-O10, A10 and N10 variants) and in $20 \mathrm{~s}$ application (in the case of oxygen-O20 variant), the germination was comparable to the untreated control. In other variants (longer application time), we recorded a significant decrease in germination. For example, a more than sixfold reduction in germination rate was observed in $\mathrm{O} 180$ and A180 variants and a more than 10-fold reduction in germination rate in the $\mathrm{O} 300$ and $\mathrm{A} 300$ variants. CAPP generated in a nitrogen atmosphere completely inhibited the germination of barley grains at application dose 60 and more seconds (N60, N180 and N300 variants) (Figure 1). 

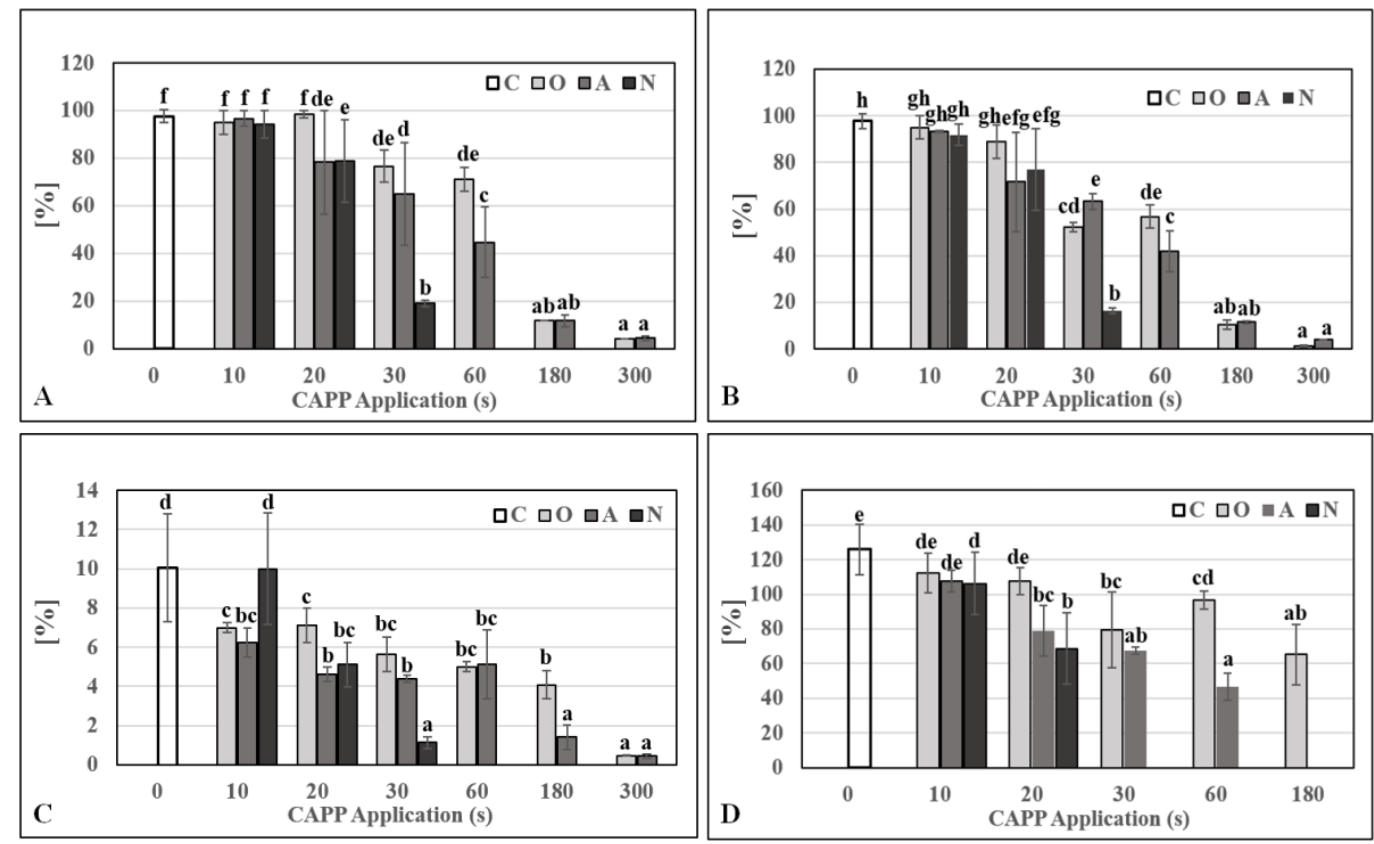

Figure 1. Germination (\%) (A), Germination Potential (\%) (B), Germination Index (\%) (C) and Grain Vigor Index (\%) (D) of barley grains after cold atmospheric pressure plasma (CAPP) treatment. Variants: C—control/untreated barley grains; O10-O300: barley grains treated with plasma generated in oxygen atmosphere for 10, 20, 30, 60, 180 or 300 s; A10-A300: barley grains treated with plasma generated in ambient air for 10, 20, 30, 60, 180 or $300 \mathrm{~s}$; N10-N300 barley grains treated with plasma generated in nitrogen atmosphere for 10, 20,30, 60, 180 or $300 \mathrm{~s}$. Different letters indicate significant difference at $p$-value $<0.05$, bars are means of ten experimental runs (one run represents 50 grains per variant, $n=500$ ) $\pm \mathrm{SD}$ according to Tukey's HSD (Honestly Significant Difference) test. Indexes were calculated according to Abdul-Baki and Anderson [26].

An interesting result was obtained in the monitoring of barley grains' germination dynamics. Treatment with low doses of plasma (variants O10, O20, O30, A10 and N10) significantly accelerated germination on the first day of culture compared to the untreated control (Figure 2). This trend also continued on the second day of cultivation. However, on the third day, the number of germinated seeds in the variants treated with low doses of plasma and untreated control were comparable. At higher plasma application doses, germination was significantly delayed. The reduced vitality of barley grains and, thus, the reduced ability to germinate were also reflected in the production parameters (length and weight of roots and shoots) of 5-day-old seedlings (Table 1). The application of CAPP for 10 and $20 \mathrm{~s}$ for all working gases and $30 \mathrm{~s}$ for oxygen and ambient air had a slight stimulating effect on the weight and length of the roots and shoots. The action of CAPP generated in a nitrogen atmosphere for $30 \mathrm{~s}$, in an oxygen atmosphere for $300 \mathrm{~s}$ and in ambient air for 180-300 s negatively affected the growth and development of roots and shoots. The seedlings were significantly deformed and stunted, so we have not presented data for these variants (N30, O300, A180 and A300) in Table 1 and they were not included in further experiments. The number of adventitious roots (in the case of variants that developed normally) did not change due to the CAPP application dose or working gas. 


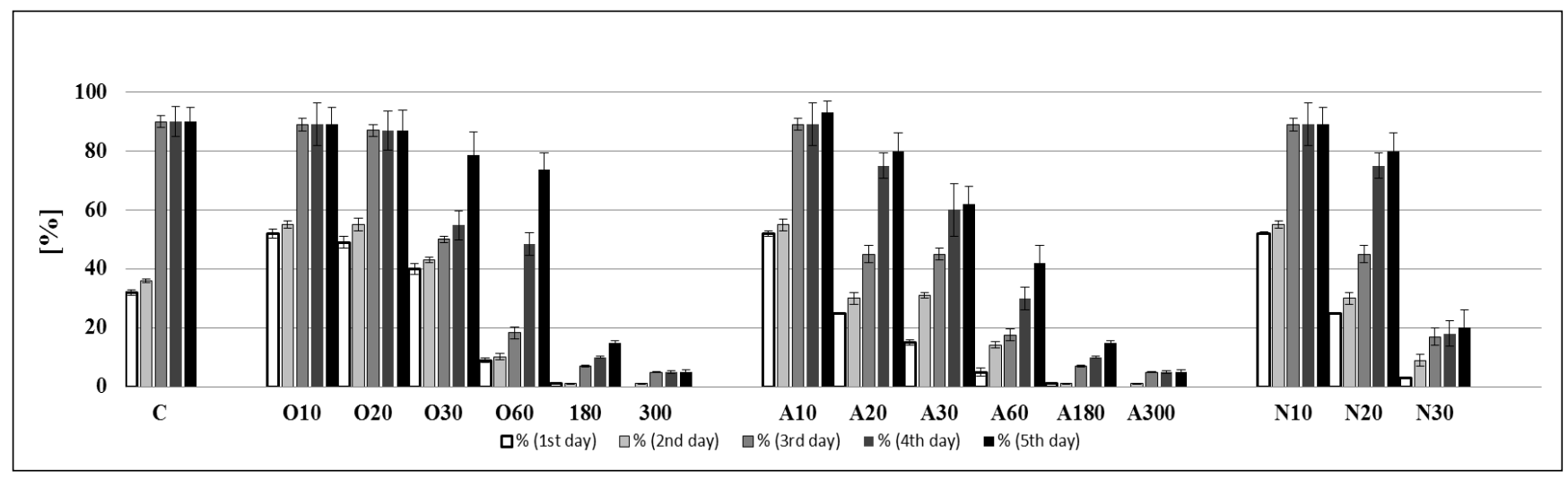

Figure 2. The dynamics of barley grain germination represented by calculated Percentage of Germination (\%) on 1st, 2nd, 3rd, 4th and 5th day of cultivation. Variants: C—control/untreated barley grains; O10-O300: barley grains treated with plasma generated in an oxygen atmosphere for 10, 20, 30, 60, 180 or 300 s; A10-A300: barley grains treated with plasma generated in ambient air for 10, 20, 30, 60, 180 or $300 \mathrm{~s}$; N10-N300 barley grains treated with plasma generated in a nitrogen atmosphere for 10, 20, 30, 60, 180 or $300 \mathrm{~s}$. Bars are means of ten experimental runs (one run represents 50 grains per variant, $n=500) \pm$ SD.

Table 1. Shoot and root length/weight and adventitious root number of 5-day-old barley seedlings after CAPP treatment.

\begin{tabular}{cccccc}
\hline $\begin{array}{c}\text { CAPP } \\
\text { Application (s) }\end{array}$ & $\begin{array}{c}\text { Average Shoot } \\
\text { Length }(\mathbf{m m})\end{array}$ & $\begin{array}{c}\text { Average Shoot } \\
\text { Weight (mg) }\end{array}$ & $\begin{array}{c}\text { Average Root } \\
\text { Length (mm) }\end{array}$ & $\begin{array}{c}\text { Average Root } \\
\text { Weight (mg) }\end{array}$ & $\begin{array}{c}\text { Adventitious } \\
\text { Root Number }\end{array}$ \\
\hline C (0) & $11.3 \pm 0.43 \mathrm{~d}$ & $81.9 \pm 17.2 \mathrm{e}$ & $6.21 \pm 0.96 \mathrm{e}$ & $69.5 \pm 16.1 \mathrm{c}$ & $6.66 \pm 0.59 \mathrm{~d}$ \\
\hline O10 & $10.2 \pm 1.11 \mathrm{~b}$ & $81.1 \pm 19.3 \mathrm{de}$ & $7.49 \pm 1.33 \mathrm{f}$ & $82.7 \pm 22.2 \mathrm{de}$ & $6.40 \pm 0.70 \mathrm{abcd}$ \\
\hline O20 & $10.3 \pm 1.91 \mathrm{bc}$ & $79.4 \pm 23.1 \mathrm{cde}$ & $5.38 \pm 1.13 \mathrm{bcd}$ & $93.0 \pm 23.6 \mathrm{e}$ & $6.18 \pm 0.60 \mathrm{abc}$ \\
\hline O30 & $11.3 \pm 0.88 \mathrm{~cd}$ & $97.5 \pm 21.7 \mathrm{e}$ & $4.17 \pm 1.11 \mathrm{a}$ & $97.0 \pm 15.7 \mathrm{e}$ & $5.85 \pm 0.69 \mathrm{a}$ \\
\hline O60 & $5.0 \pm 1.05 \mathrm{a}$ & $63.2 \pm 13.3 \mathrm{ab}$ & $4.61 \pm 1.32 \mathrm{ab}$ & $58.8 \pm 17.2 \mathrm{ab}$ & $6.47 \pm 0.68 \mathrm{bcd}$ \\
\hline O180 & $4.9 \pm 0.98 \mathrm{a}$ & $65.0 \pm 14.3 \mathrm{abc}$ & $5.12 \pm 1.29 \mathrm{bcd}$ & $48.8 \pm 15.5 \mathrm{a}$ & $6.17 \pm 0.85 \mathrm{ab}$ \\
\hline A10 & $11.3 \pm 1.11 \mathrm{~d}$ & $86.4 \pm 22.6 \mathrm{ef}$ & $6.55 \pm 0.84 \mathrm{ef}$ & $84.7 \pm 24.7 \mathrm{de}$ & $6.60 \pm 0.70 \mathrm{bcd}$ \\
\hline A20 & $11.0 \pm 1.55 \mathrm{bcd}$ & $87.3 \pm 22.3 \mathrm{ef}$ & $6.48 \pm 0.77 \mathrm{e}$ & $68.5 \pm 19.6 \mathrm{bc}$ & $6.90 \pm 0.57 \mathrm{~d}$ \\
\hline A30 & $10.9 \pm 1.01 \mathrm{bcd}$ & $87.8 \pm 22.2 \mathrm{ef}$ & $4.70 \pm 0.78 \mathrm{abcd}$ & $75.0 \pm 21.4 \mathrm{~cd}$ & $6.75 \pm 0.46 \mathrm{bcd}$ \\
\hline A60 & $5.3 \pm 1.01 \mathrm{a}$ & $54.7 \pm 17.0 \mathrm{a}$ & $4.78 \pm 0.99 \mathrm{abc}$ & $54.2 \pm 17.3 \mathrm{ab}$ & $6.67 \pm 0.93 \mathrm{~d}$ \\
\hline $\mathrm{N} 10$ & $11.5 \pm 0.63 \mathrm{~d}$ & $80.1 \pm 18.6 \mathrm{de}$ & $5.51 \pm 1.25 \mathrm{c}$ & $76.4 \pm 18.5 \mathrm{~cd}$ & $6.51 \pm 0.76 \mathrm{bcd}$ \\
\hline $\mathrm{N} 20$ & $10.9 \pm 1.64 \mathrm{bcd}$ & $72.5 \pm 17.7 \mathrm{bcd}$ & $5.45 \pm 0.59 \mathrm{~cd}$ & $53.3 \pm 17.6 \mathrm{a}$ & $6.65 \pm 0.85 \mathrm{~cd}$ \\
\hline
\end{tabular}

Variants: C-control/untreated barley grains; O10-O300: barley grains treated with plasma generated in an oxygen atmosphere for 10, 20, 30, 60, 180 or $300 \mathrm{~s}$; A10—A300: barley grains treated with plasma generated in ambient air for 10, 20, 30, 60, 180 or 300 s; N10—N300 barley grains treated with plasma generated in a nitrogen atmosphere for 10, 20, 30, 60, 180 or $300 \mathrm{~s}$. Different letters indicate significant difference at $p$-value $<0.05$, data represent means of ten experimental runs (one run represents 50 grains per variant, $n=500$ ) $\pm \mathrm{SD}$ according to Tukey's HSD test.

\subsection{Enzyme Activities}

The activity of protease was positively affected after 10, 20 and $30 \mathrm{~s}$ treatment of plasma (for all working gases) and its activity decreased significantly with prolonged plasma exposure. Interestingly, glucanase activity was significantly higher in all plasma treated variants (compared to the untreated control), peaked at $60 \mathrm{~s}$ plasma treatment, and then decreased sharply (Figure 3). Using the Bradford method [27], a positive effect on the concentration of total soluble proteins in variants $\mathrm{O} 10, \mathrm{O} 20, \mathrm{O} 30$ and A20 was recorded (Figure 4). 

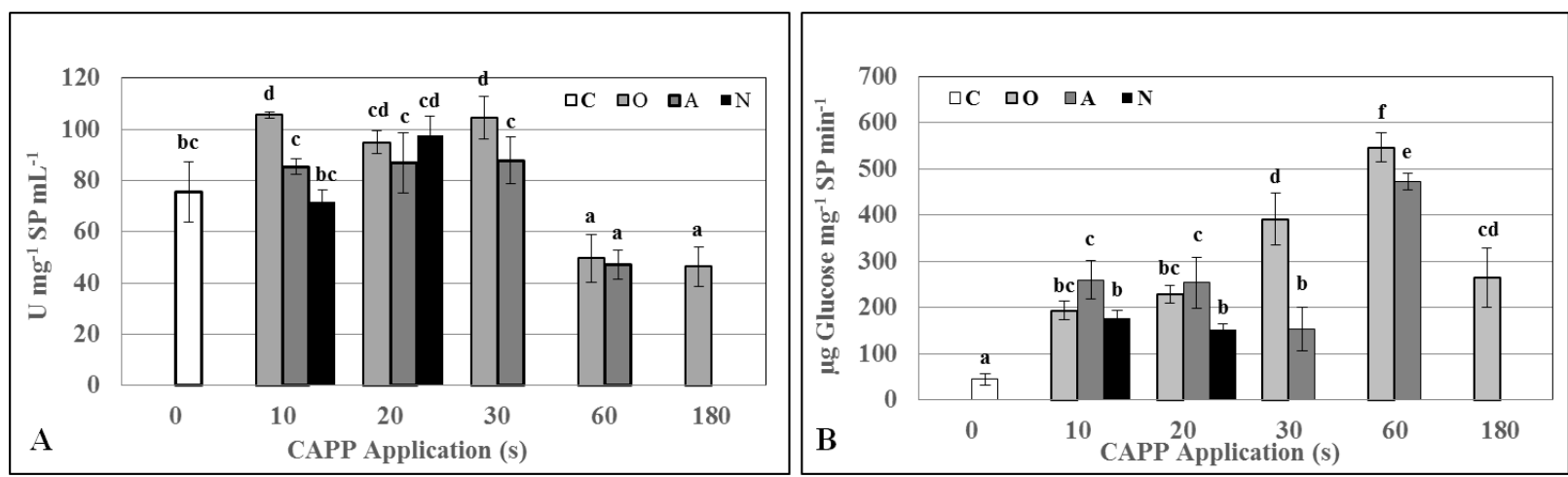

Figure 3. Activities of protease (A) and glucanase (B) in 3-day old barley seedlings after CAPP treatment. Variants: C-control/untreated barley grains; O10-O300: barley grains treated with plasma generated in oxygen atmosphere for 10, 20, 30, 60, 180 or 300 s; A10-A300: barley grains treated with plasma generated in ambient air for 10, 20, 30, 60, 180 or 300 s; N10-N300 barley grains treated with plasma generated in nitrogen atmosphere for 10, 20, 30, 60, 180 or $300 \mathrm{~s}$. Different letters indicate significant difference at $p$-value $<0.05$, bars are means of ten experimental runs (one run represents 50 seeds per variant; three 1.5-g mixed samples were analyzed per experimental run and each variant for protease and glucanase activities) \pm SD according to Tukey's HSD test.

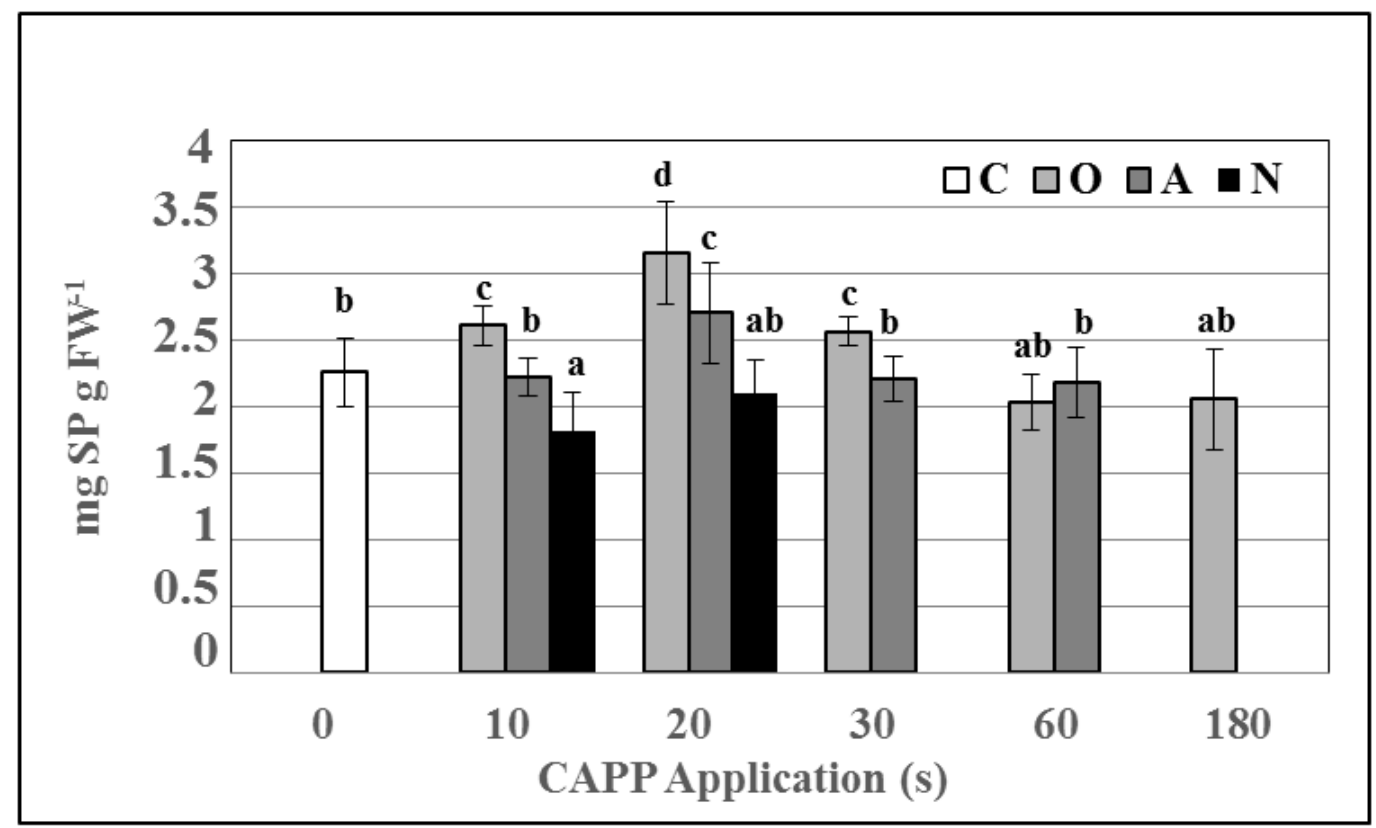

Figure 4. Total soluble protein concentration in 3-day-old barley seedlings after CAPP treatment. Variants: Ccontrol/untreated barley grains; O10-O300: barley grains treated with plasma generated in an oxygen atmosphere for 10, 20, 30, 60, 180 or 300 s; A10-A300: barley grains treated with plasma generated in ambient air for 10, 20, 30, 60, 180 or 300 s; N10-N300 barley grains treated with plasma generated in a nitrogen atmosphere for 10, 20, 30, 60, 180 or 300 s. Different letters indicate significant difference at $p$-value $<0.05$, bars are means of ten experimental runs (one run represents 50 seeds per variant; three 1.5-g mixed samples were analyzed per experimental run and each variant for soluble protein concentration) \pm SD according to Tukey's HSD test.

When monitoring the activity of antioxidant enzymes, lower plasma doses slightly stimulated superoxide dismutase activity (SOD), with statistically significant increases in SOD activity observed in variant A30. The activity of guaiacol peroxidase (G-POX) decreased slightly after $10 \mathrm{~s}$ treatment compared to the untreated control, peaked after $20 \mathrm{~s}$ treatment and subsequently began to decrease with increasing application dose (Figure 5). 


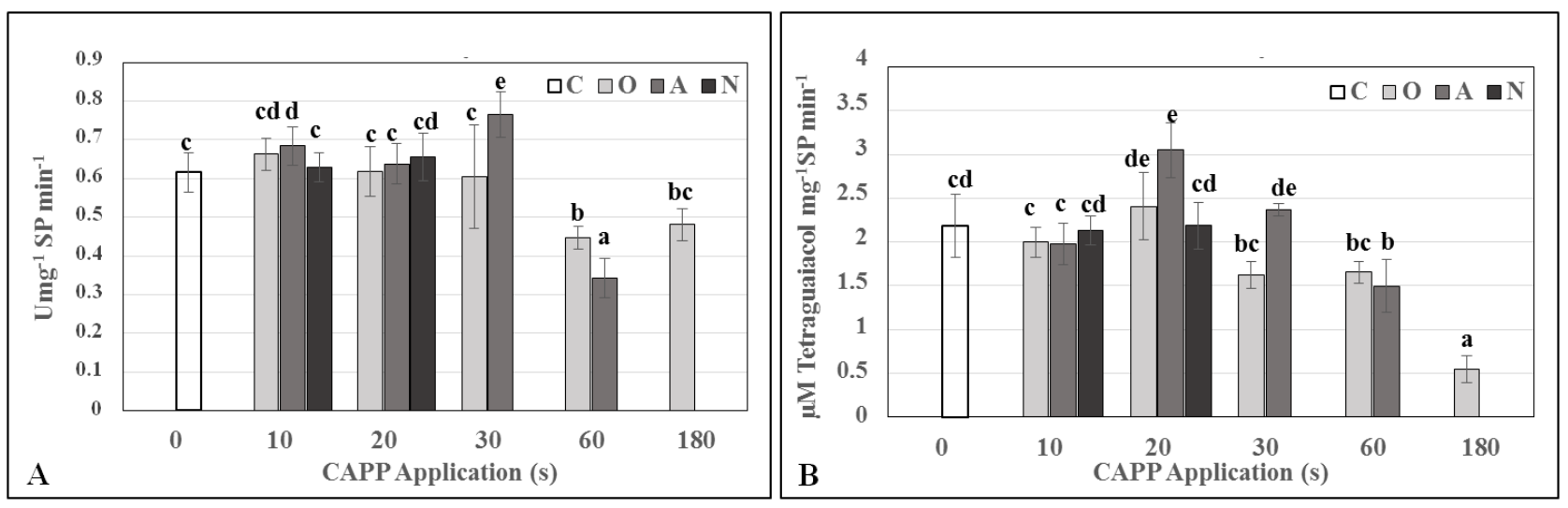

Figure 5. Activities of superoxide dismutase (SOD) (A) and guaiacol peroxidase (G-POX) (B) in 3-day-old barley seedlings after CAPP treatment. Variants: C—control/untreated barley grains; O10-O300: barley grains treated with plasma generated in oxygen atmosphere for 10, 20, 30, 60, 180 or $300 \mathrm{~s}$; A10-A300: barley grains treated with plasma generated in ambient air for 10, 20, 30, 60, 180 or 300 s; N10-N300 barley grains treated with plasma generated in nitrogen atmosphere for 10, 20, $30,60,180$ or $300 \mathrm{~s}$. Different letters indicate significant difference at $p$-value $<0.05$, bars are means of four experimental runs (one run represents 50 seeds per variant; three 1.5-g mixed samples were analyzed per experimental run and each variant) \pm SD according to Tukey's HSD test.

\subsection{Genotoxic Effects}

The genotoxic potential of CAPP treatment on barley grains was estimated by standard and modified alkaline comet assays and constant field gel electrophoresis (CFGE) on 7day-old seedlings. As shown in Figure 6, DNA damage was statistically significantly higher compared to control samples $(8.08 \%)$ analyzed by comet assay at all exposure times. Moreover, the amount of DNA damage rose with increasing CAPP application. The highest rates of DNA damage were observed in samples treated by plasma generated in ambient air for $60 \mathrm{~s} \mathrm{(38 \% )} \mathrm{and} \mathrm{decreased} \mathrm{at} \mathrm{lower} \mathrm{exposure} \mathrm{times} \mathrm{from} 30$ to $10 \mathrm{~s}$ (from $19.38 \%$ to $17.03 \%)$. DNA damage in samples treated with plasma generated in oxygen rose with increasing time from $19.08 \%$ (10 s) to $23.14 \%$ (30 s). The least DNA damage was observed in samples treated with plasma generated in nitrogen, where the values ranged from $13.91 \%$ (20 s) to $16.25 \%$ (30 s).

The alkaline comet assay is the method used for the detection of DNA single- and double-strand breaks. Moreover, modification of this method using the formamidopyrimidine DNA glycosylase (Fpg) enzyme also enables the detection of oxidative damage of purines. In our study (Figure 7), we did not observe a statistically significant increase in DNA breaks and oxidation damage in samples treated with plasma generated in nitrogen compared to the negative control (10.3\%). However, the rate of these types of DNA damage increased similarly in samples treated with plasma generated in ambient air and oxygen at all exposure times. A comparison of Figures 6 and 7 shows that the values detected by comet assay modified with Fpg enzyme were higher than those by standard comet assay in all samples treated with plasma generated in ambient air or oxygen. These results suggest that treatment with these types of plasma resulted in purine oxidation. However, DNA damage analyzed by modified and standard comet assays did not reveal evident differences in samples treated with plasma generated in nitrogen, showing that this plasma type did not cause purine oxidation. 


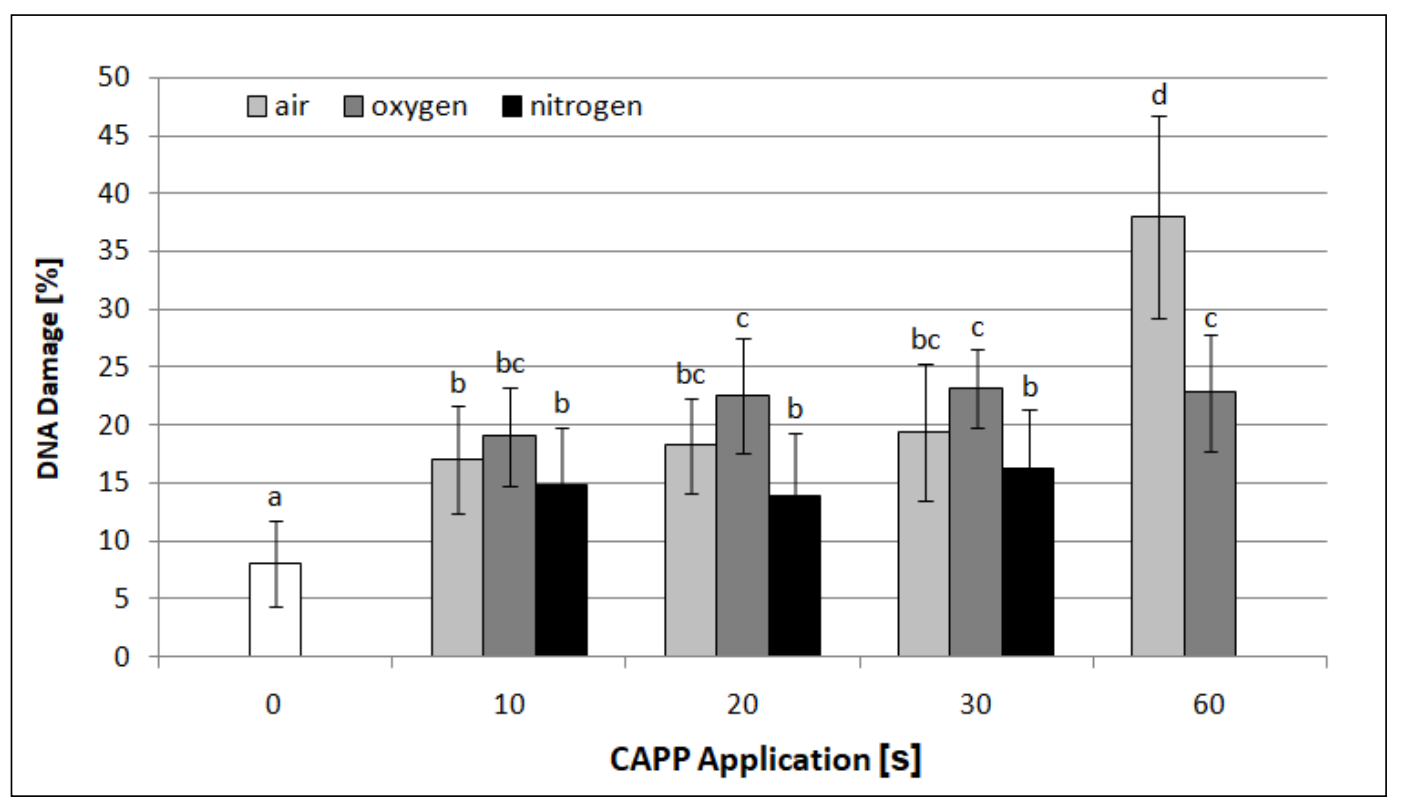

Figure 6. Graphical representation of the DNA damage effect of CAPP generated in ambient air, oxygen and nitrogen at exposure times of 10-60 s in barley leaves analyzed by comet assay. At least 100 nuclei were analyzed per slide. The data were analyzed using the statistical method LSD (Least Significant Difference) ANOVA and comparisons between the mean values were considered significant at $p \leq 0.05$. Bars are means of three experimental runs $\pm \mathrm{SD}$.

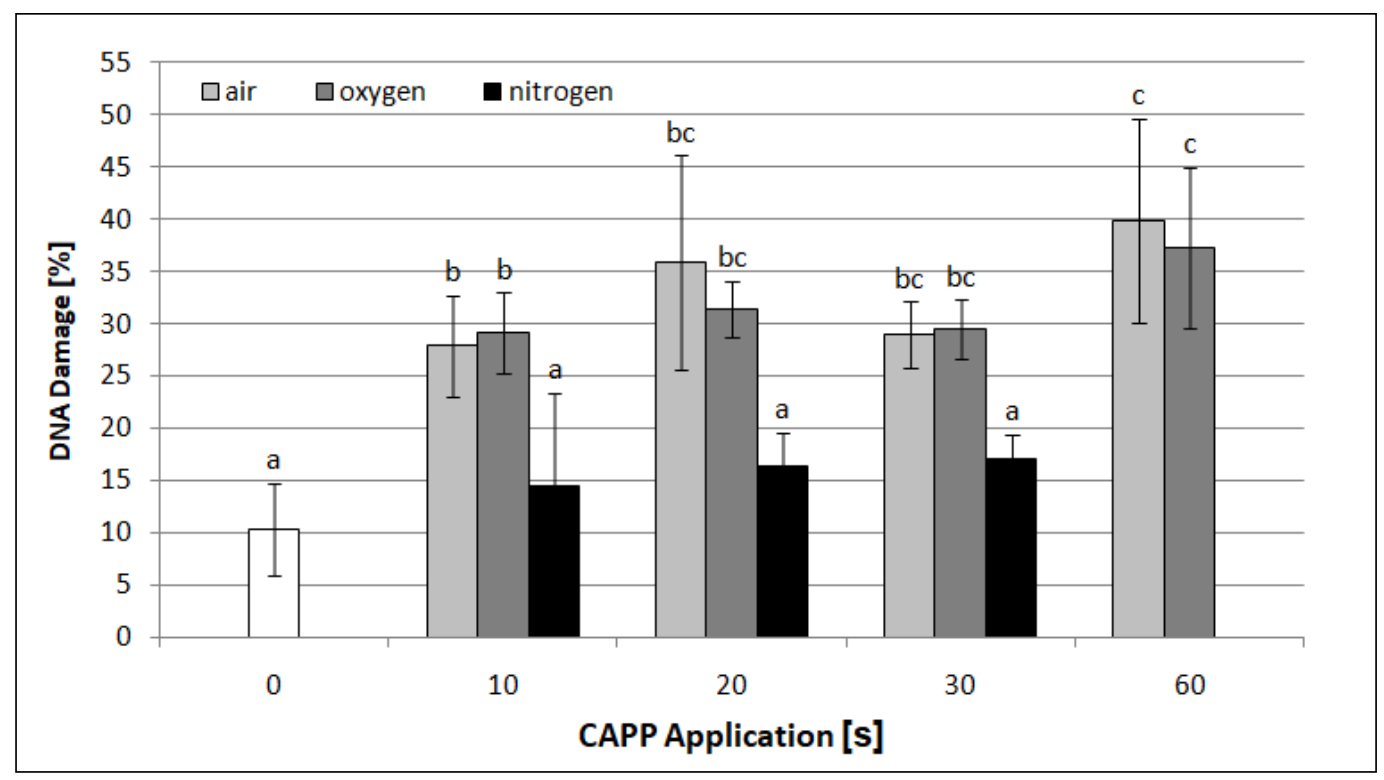

Figure 7. Graphical representation of the DNA damage effect of CAPP generated in ambient air, oxygen and nitrogen at exposure times of 10-60 s in barley leaves, analyzed by comet assay modified with formamidopyrimidine DNA glycosylase (Fpg). At least 200 nuclei were analyzed per slide. The data were analyzed using the statistical method LSD ANOVA and comparisons between the mean values were considered significant at $p \leq 0.05$. Bars are means of three experimental runs \pm SD.

As by comet assay, it is possible to detect both, single- and double-strand breaks, the CFGE method was used for double-strand break evaluation specifically. As shown in Figure 8, the relative amount of DNA double-strand breaks increased only at longer exposure times. The highest and only statistically significant increase compared to control samples was observed in 60-s exposure to plasma generated in ambient air (1.27-fold). These results suggest that CAPP treatment does not induce DNA double-strand break for- 
mation and that DNA damage observed by standard comet assay was mainly represented by single-strand breaks.

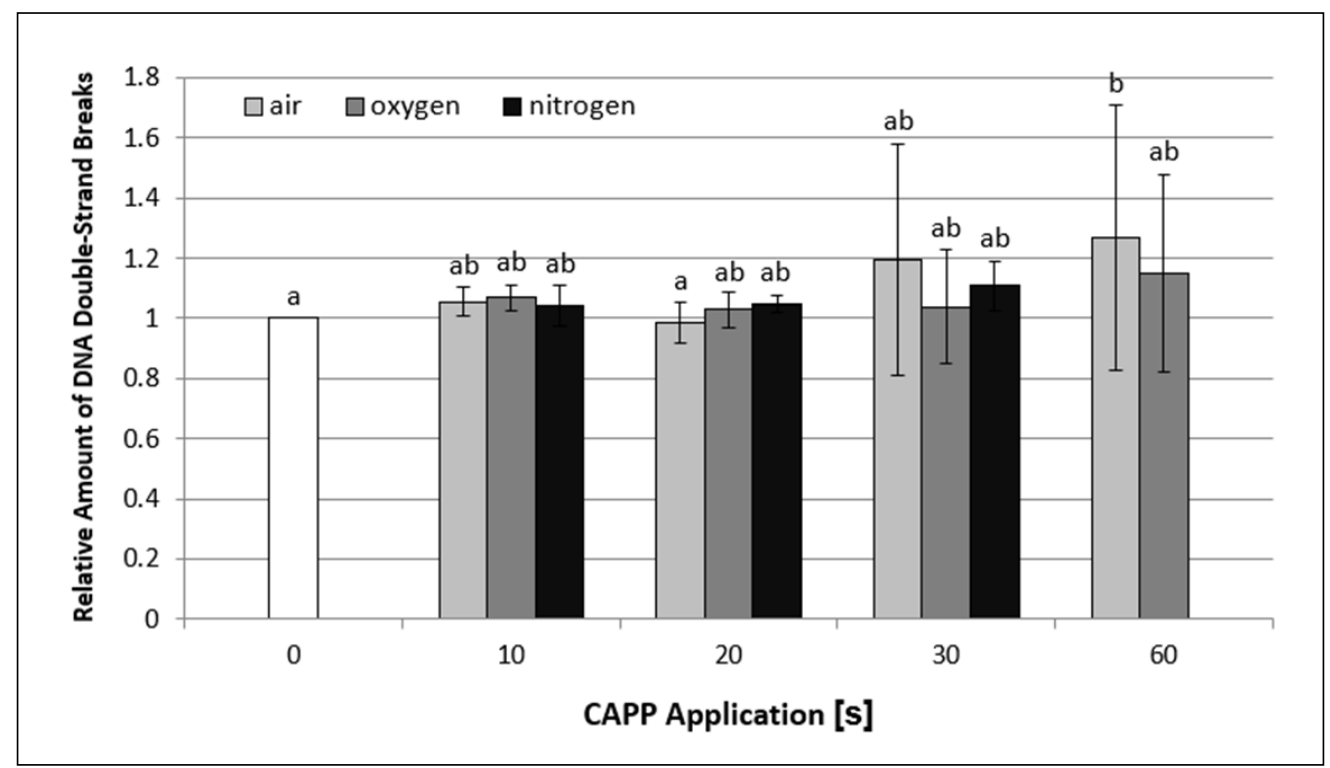

Figure 8. Graphical representation of the CAPP generated in ambient air, oxygen and nitrogen at exposure times of 10-60 s on the degree of double-strand breaks in barley leaves' DNA, analyzed by constant field gel electrophoresis (CFGE). The data were analyzed using the statistical method LSD ANOVA and comparisons between the mean values were considered significant at $p \leq 0.05$. Bars are means of three experimental runs $\pm \mathrm{SD}$.

\section{Discussion}

It has been shown that plasma exposure affects seed germination differently depending on various factors including the type of the plasma source, working gas and exposure time [28,29], plant species [30] or even seed/grain cultivation conditions [31]. For example, while wheat grain germination was accelerated by cold plasma discharge treatment, both germination rate and germination speed of oat grains were unaffected by different time exposures to plasma [30]. Similarly, in our study, germination of barley grains (Hordeum vulgare L. cv. Maltz) was significantly accelerated after treatment with low doses of cold atmospheric pressure plasma (up to $30 \mathrm{~s}$ ) on the initial days of cultivation compared to the untreated control. Park et al. [32] state that surface dielectric barrier discharge did not show a remarkable difference in the early germination beginnings of two barley cultivars (Saechal-waxy hull-less barley; Saessal-non-waxy hull-less barley cultivar developed in Korea). After artificial infecting of barley grains with pathogenic fungi of the genus Fusarium and subsequent plasma treatment with low-pressure $\mathrm{Ar} / \mathrm{N}_{2}-\mathrm{O}_{2}$ surface-wave microwave discharges for $3 \mathrm{~min}$, Szöke et al. [33] noted an increase in the germination of infected seeds above $80 \%$. However, the germination and vigor of non-infected barley grains were not significantly affected after plasma treatment. Positive effects of nonthermal plasma application on seed germination (after optimal application doses) have been observed in a great variety of plant species, including monocots,-e.g., maize [34], wheat [30,35] and rice [36] —and dicot plants-e.g., Chenopodium album [37], pea [16,38], soybean [39,40] and tomato [31]. As in our study, the negative effect of high application rates of non-thermal plasma, and in particular, the negative effect of nitrogen as a working gas, has recently been described, e.g., for peas and soybeans [38,40-42]. The sensitivity of barley grains to prolonged plasma doses, which represent a highly reactive environment [42], can be explained by the thin coating of the grains. In addition, it was found that in contrast to its wild relatives, cultivated barley does not accumulate substantial amounts of proanthocyanidins (PAs) [43], which first condense into tannins and then oxidize to brown pigmentation seen in the mature seed of many species [44], and PAs are closely 
related to stress responses [45]. Several authors agree that the application of plasma can partially disrupt/modify the layers of seed/grain coatings, and thus, reactive particles can penetrate deeper and directly interact with the storage tissues or directly with the embryo $[16,32,38,46]$.

We found that low doses of CAPP generated in various working gases slightly stimulate the activity of antioxidant enzymes (SOD and G-POX) involved in the detoxification of RONS. This is very important in managing oxidative stress. Moreover, our data show that it can also alleviate waterlogging stress, which is a major abiotic stress for barley [47]. Restoration of the metabolic activity of dormant seeds/grains is another important part of the germination story. In the case of cereals, the endosperm is an embryonic tissue highly specialized for nutrient storage, containing organelles (protein bodies and protein storage vacuoles) for the accumulation of storage proteins and sugars. Fully developed cereal endosperm represents approximately $75 \%$ of the grain weight and consists of four types of cell layers: aleurone, starchy endosperm, transfer cells and the cells of the embryo-surrounding region [48]. The starchy endosperm is characterized as a storage site, accumulating starch and seed storage proteins. The aleurone layers play essential roles during seed germination, where during imbibition, lytic enzymes [49] are activated by the action of gibberellic acid $[50,51]$. Many authors agree that the germination acceleration after plasma treatment is due to the faster activation of lytic enzymes [32,38-40,52]. Our results correlate with these findings and we confirmed that low plasma doses stimulate both protease and glucanase activities in barley grains. This resulted in a slight increase in the concentration of total soluble protein and better production parameters of young barley seedlings. Los et al. [53] reported improvement of production parameters (length of roots and shoots) of 7-day-old wheat seedlings after 30 and $60 \mathrm{~s}$ treatment with cold plasma. Park et al. [32] observed faster growth of plasma-treated barley hypocotyls (at least $15 \%$ or maximum $110 \%$ ) than non-treated samples.

As we mentioned before, plasma decontamination effects are probably caused by RONS, which can attack nearby cells and oxidize macromolecules, even DNA. It is the reason why we focused also on the genotoxic potential of plasma using three methods for oxidized bases, DNA single- and double-strand breaks detection. According to our results, we suggest that the least harmful working gas for barley grains treatment is nitrogen, where the number of primary DNA damages was the lowest one from all monitored working gases. However, these results differ from other studies where the same plasma source, diffuse coplanar surface barrier discharge (DCSBD), for various seeds' treatment was used. In the study of Švubová et al. [40], plasma generated from ambient air was the most suitable for soybean treatment. The number of DNA breaks in soybean seedlings after $30 \mathrm{~s}$ treatment with plasma generated in ambient air was on the same level as in control samples. Similar results were observed also in study of Tomeková et al. [42], where $60 \mathrm{~s}$ treatment with plasma generated in ambient air resulted only in a slight (1.6-fold) increase in DNA damage in pea seedlings. However, pea seed treatment with plasma generated from nitrogen caused approximately a fourfold higher level of DNA damage. Švubová et al. [38] observed the same results in single-strand break formation on pea seedlings after plasma treatment as in the previously mentioned studies. Similar to our study, the amount of double-strand breaks was comparable to the level of plasma-untreated samples. Indirect plasma effects on barley plants through plasma-activated water were observed by Ndiffo-Yemeli et al. [54] and, in comparison to our results, a significant increase in DNA damage was not observed. Differences in the results of our and other studies could be caused by different plasma treatment conditions, models organisms and their responses to plasma treatment. Single-strand break formation was observed also on the plasmid DNA treated by CAPP in many studies [55-57]. In the study by O'Connell et al. [55], CAPP generated from helium with oxygen addition primarily caused single-strand breaks in the plasmid DNA; however, with increasing treatment time, double-strand break formation occurred too. Moreover, with increasing concentration of atomic oxygen in plasma, the amount of double-strand breaks increased. This suggests that mainly atomic oxygen 
generated by plasma may be responsible for DNA break formation. Similar results were observed by Alkawareek et al. [56] on plasmid DNA treated by CAPP generated from helium with oxygen addition. The number of double-strand breaks in plasmid DNA was higher with increasing oxygen concentration in plasma. These studies suggest that DNA damage depends on the working gas. Reactive species present in the plasma generated in different working gases vary from each other in the stability and affinity to DNA [58]. The differences in our results and those of studies with plasmid treatment could be caused due to the fact that plasmid DNA is bare and unprotected. However, the DNA of plant cells interacts with proteins and is protected by a nuclear membrane, plasma membrane and cell wall.

\section{Materials and Methods}

\subsection{Plant Material}

The dried barley (Hordeum vulgare L. cv. Maltz) grains used in the experiments were obtained from the Central Control and Testing Institute in Agriculture in Bratislava, Slovakia. The seeds were stored at $8{ }^{\circ} \mathrm{C}$ in the dark.

\subsection{Plasma Generation and Samples Treatment}

Plasma is usually denoted as the fourth state of matter. Adding energy into a gas leads to ionization and formation of a chemically very active medium consisting of electrons, ions, excited atoms and molecules, metastable atoms and molecules and radiation [59]. For surface modification of materials, plasma is generated by electric discharges operating in a wide variety of electrodes' geometry. The properties of plasma can be adjusted in terms of required processes by different working gases, modes of supply (frequency, voltage and input power), operating pressure, etc. [60,61].

The plasma treatment of barley samples was realized by a special type of atmospheric pressure discharge called diffuse coplanar surface barrier discharge (DCSBD) [62]. Unique design and optimized geometry allow the generation of low-temperature macroscopically uniform diffuse plasma in any working gas, even in electronegative, e.g., oxygen [63]. DCSBD consists of an alumina ceramic plate with two systems of parallel strip-like electrodes on the bottom side with alternating polarity of adjacent strips.

Plasma is generated in a thin layer on the surface of ceramics with active thickness in the range of $0.3-0.5 \mathrm{~mm}$. The size of the discharge area $(8 \times 20 \mathrm{~cm})$ enables the plasma treatment of a high amount of material. The generated plasma is characterized by high surface $\left(1-3 \mathrm{~W} / \mathrm{cm}^{2}\right)$ and volume $\left(\sim 80 \mathrm{~W} / \mathrm{cm}^{3}\right)$ power density resulted in short exposure times [17].

The experimental apparatus is shown in Figure 9. The DCSBD was placed on an orbital shaker and the homogeneity of samples' treatment was ensured by the movement of samples at $330 \mathrm{rpm}$. The DCSBD was powered by a sinusoidal voltage of $20 \mathrm{kV}$ (peak to peak) and a frequency of $15 \mathrm{kHz}$. The input power supplied to the DCSBD was $400 \mathrm{~W}$ and up to 50 barley seeds were placed in the DCSBD discharge area. The treatment was realized in a closed chamber in laboratory air and in oxygen or nitrogen in a flow regime with a flow rate of $3 \mathrm{Lpm}$ and was the same for each working gas. Exposure times were 10, 20, 30, 60, 180 and 300 s for each working gas. 


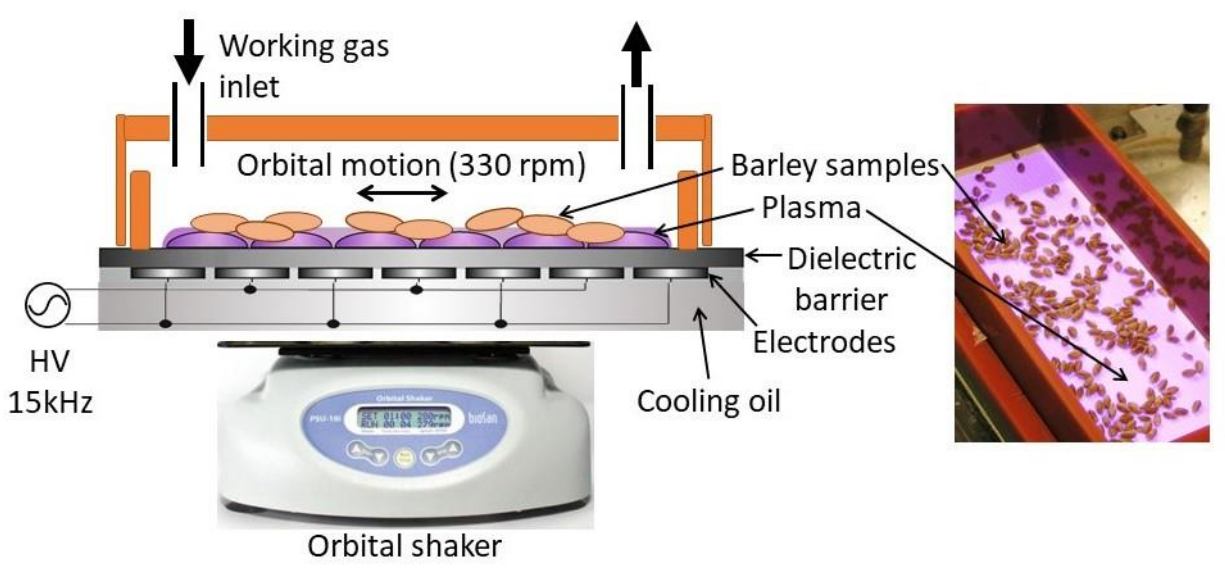

Figure 9. Scheme of the experimental apparatus with diffuse coplanar surface barrier discharge (DCSBD) and picture of barley samples' exposure in plasma.

\subsection{Germination and Growth Conditions}

Dry barley grains (50 for each variant) were sown on Petri dishes on sterile filter paper, watered and cultivated in dark conditions in an incubator at the temperature of $24 \pm 2{ }^{\circ} \mathrm{C}$ for 5 days. During cultivation, the number of germinated grains was counted and, on the third day, material for biochemical analyses (enzyme activity assays) was collected. After 5 days, the length $(\mathrm{cm})$ and weight $(\mathrm{mg})$ of shoots and roots were measured and the number of adventitious roots of young seedlings was counted. These data were used to calculate Germination (\%), Germination Potential (\%), Germination Index (\%) and Grain Vigor Index (\%) according to Abdul-Baki and Anderson [26]. Changes in germination during 5-day-long cultivation were used to express the germination dynamics of barley grains.

\subsection{Total Soluble Proteins Content}

Samples ( 1.5 g) were ground in liquid nitrogen with a mortar and pestle and suspended in $50 \mathrm{mM}$ Na-Phosphate protein extraction buffer with $1 \mathrm{mM}$ EDTA (pH 7.8). After 15 min centrifugation $(12,000 \times g)$, the supernatant was used for the determination of protein concentration according to Bradford [27]. Total soluble protein content was calculated as the amount of total proteins per gram of fresh matter from the calibration curve. As the protein standard, we used bovine serum albumin (BSA). All chemicals were purchased from Sigma-Aldrich Co.

\subsection{Protease and Glucanase Activity Assays}

Changes in the proteolytic activity in 3-day-old barley seedlings were determined by incubating $150 \mu \mathrm{L}$ of an extracted protein sample with $150 \mu \mathrm{L}$ of $2 \%(w / v)$ BSA in $200 \mathrm{mM}$ glycine- $\mathrm{HCl}$ buffer ( $\mathrm{pH} \mathrm{3.0)}$ ) at $37^{\circ} \mathrm{C}$ for $1 \mathrm{~h}$. The reaction was stopped by the addition of $450 \mu \mathrm{L}$ of $5 \%(w / v)$ trichloroacetic acid. Samples were incubated on ice for $10 \mathrm{~min}$ and centrifuged at $20,000 \times \mathrm{g}$ for $10 \mathrm{~min}$ at $4{ }^{\circ} \mathrm{C}$. The absorbance of the supernatant was measured at $280 \mathrm{~nm}$ by a Jenway $6705 \mathrm{UV} /$ Vis spectrophotometer (Bibby Scientific Ltd., Essex, UK). One unit of proteolytic activity is defined as an increase of 0.001 in the absorbance at $280 \mathrm{~nm}$ per min [64]. The activity of $\beta-1,3$-glucanase was assayed by measuring the release rate of reducing sugar from laminarin as substrate according to the methodology of Somogyi [65] and Nelson [66]. Absorbance was measured by a Jenway $6705 \mathrm{UV} /$ Vis spectrophotometer at $660 \mathrm{~nm}$. Total enzyme activity was calculated from the calibration curve as a reduction in glucose $\mathrm{min}^{-1} \mathrm{mg}^{-1} \mathrm{SP}$. As a standard, we used glucose. All chemicals were purchased from Sigma-Aldrich Co. 
4.6. Assays of Guaiacol Peroxidase (POX, E.C.1.11.1.7) and Superoxide Dismutase (SOD, E.C.1.15.1.1) Activities

The activities of enzymes that detoxify $\mathrm{H}_{2} \mathrm{O}_{2}$ (POX, E.C.1.11.1.7) and $\mathrm{O}^{2-}$ (SOD, E.C.1.15.1.1) were tested. The activity of guaiacol peroxidase (G-POX) was established according to Frič and Fuchs [67], and the activity of superoxide dismutase (SOD) according to Beauchamp and Fridovich [68]. One unit of SOD activity is the amount of proteins required to inhibit $50 \%$ initial reduction in nitrotetrazolium blue chloride (NBT) under the light. G-POX activity is expressed in $\mu \mathrm{M}$ of tetraguaiacol $\mathrm{min}^{-1} \mathrm{mg}^{-1}$ by molar extinction coefficient of tetraguaiacol (26.6). All chemicals were purchased from Sigma-Aldrich Co.

\subsection{Alkaline Comet Assay}

The alkaline comet assay is a method used for measuring DNA damage in eukaryotic cells. Using the alkaline comet assay and its modifications, it is possible to detect different DNA defects such as single-strand breaks, double-strand breaks, cross-links, apyrimidine and apurine (AP) sites $[69,70]$. Our experiments were performed according to Gichner et al. [71] with a few modifications [41,72]. Briefly, two leaves of 7-day-old seedlings for each sample were cut using a razor blade, ensuring DNA release in $175 \mu \mathrm{L}$ of $0.4 \mathrm{M}$ Tris- $\mathrm{HCl}$ buffer solution ( $\mathrm{pH}$ 7.5) (Sigma-Aldrich Co.) because of the mechanical disruption of the cell and nuclear walls. The slicing and releasing of the DNA were realized in the dark and on ice. After that, $100 \mu \mathrm{L}$ of the DNA and buffer suspension was mixed with $100 \mu \mathrm{L}$ of $1 \%$ low melting point agarose (Roth). The final solution was then placed on a slide covered with $1 \%$ normal melting point agarose (Roth) and then covered with a coverslip. The coverslips were removed after $5 \mathrm{~min}$ and $40 \mu \mathrm{L}$ of formamidopyrimidine DNA glycosylase (Fpg, the concentration of $0.2 \mathrm{U}$ ) for oxidized purine detection was pipetted on half of each slide. After that, the slides were covered by coverslips and incubated for $30 \mathrm{~min}$ at $37^{\circ} \mathrm{C}$. After incubation, the coverslips were removed and the slides were placed in an electrophoretic chamber filled with a cold electrophoretic buffer solution containing $1 \mathrm{mM}$ EDTA (Sigma-Aldrich Co.) and $300 \mathrm{mM} \mathrm{NaOH}$ (Centralchem) for $8 \mathrm{~min}$. After that, electrophoresis was launched at $1.25 \mathrm{Vcm}^{-1}$ for $15 \mathrm{~min}$ at $4{ }^{\circ} \mathrm{C}$. Slides were then neutralized three times with $0.4 \mathrm{M}$ Tris- $\mathrm{HCl}$ buffer solution ( $\mathrm{pH}$ 7.5) and stained with fluorescent dye ethidium bromide $(0.05 \mathrm{mM}, 80 \mu \mathrm{L}$ for each slide) (Serva) for $5 \mathrm{~min}$. DNA damage was observed using an OLYMPUS BX 51 fluorescent microscope with a green excitation filter UMWIG3 under $400 \times$ magnification. Plasma-untreated seedlings were used as a negative control.

\subsection{Constant Field Gel Electrophoresis}

Constant field gel electrophoresis (CFGE) is a genotoxicological method based on the incorporation of isolated nucleoids into agarose plugs that subsequently undergo lysis and electrophoresis at a constant and low voltage. In this way, it is possible to evaluate the relative amount of double-strand breaks produced by the action of a potentially genotoxic agent [73]. Our experiments were performed according to Švubová et al. [38]. At first, two leaves of 7-day-old seedlings for each sample were cut using a razor blade in $175 \mu \mathrm{L}$ of 0.4 M Tris- $\mathrm{HCl}$ buffer solution ( $\mathrm{pH}$ 7.5) (Sigma-Aldrich Co.). This process was realized in the dark and on ice. After that, $45 \mu \mathrm{L}$ of the DNA and buffer suspension was mixed with $85 \mu \mathrm{L}$ of $0.8 \%$ low melting point agarose (Roth). Subsequently, $85 \mu \mathrm{L}$ of the final solution was transferred into $100 \mu \mathrm{L}$ sample holder and cooled at $4{ }^{\circ} \mathrm{C}$ for $1 \mathrm{~h}$. Solid agarose plugs were placed into glass tubes filled with $750 \mu \mathrm{L}$ of lysis solution (pH 8) containing $2 \%$ N-laurylsarcosine (AppliChem), 0.1\% proteinase K (Sigma-Aldrich Co.) and $0.5 \mathrm{M}$ EDTA (Sigma-Aldrich Co.). After that, tubes with agarose plugs were incubated at $4{ }^{\circ} \mathrm{C}$ for $30 \mathrm{~min}$, and after that, at $37^{\circ} \mathrm{C}$ for $18 \mathrm{~h}$. The lysis solution was then removed and agarose plugs were washed four times with TE (Tris-EDTA) solution ( $\mathrm{pH}$ 8) containing $10 \mathrm{mM}$ Tris base and $1.25 \mathrm{mM}$ EDTA (both Sigma-Aldrich Co.). Agarose plugs were then incubated in the same TE solution for $30 \mathrm{~min}$ and, afterward, were placed in wells of $0.8 \%$ agarose gel. After that, the gel was placed in an electrophoresis chamber filled with TBE 
(Tris-borate-EDTA) solution ( $\mathrm{pH} 8.3$ ) containing $45 \mathrm{mM}$ Tris base, $1.25 \mathrm{mM}$ EDTA and $45 \mathrm{mM}$ boric acid (all three from Sigma-Aldrich Co.). Electrophoresis was launched at $20 \mathrm{~V}$ for $48 \mathrm{~h}$ and the gel was visualized by the GelCapture program (version 4.24) using a DNR Bio-Imaging Systems Ltd. transilluminator. After that, the DNA amount was quantified using the ImageJ program, and final values of the relative damage rates were obtained by the ratio between migrated and total DNA amounts in gel normalized to the negative control (plasma-untreated samples) [74].

\subsection{Statistical Analyses}

Data were analyzed using Statgraphics Centurion XV v. 15.2.05 (StatPoint, Inc., Warrenton, VA, USA) and Excel (Microsoft Office 2007). Treatment effects were analyzed by means of ANOVA single-step multiple comparisons of means using means of LSD tests or Tukey's test and comparisons between the mean values were considered significant at $p \leq 0.05$. All experimental data in this work are from at least three independent experiments.

\section{Conclusions}

Low plasma doses (up to $20 \mathrm{~s}$ for ambient air and nitrogen and up to $30 \mathrm{~s}$ for oxygen) have a positive effect on the germination dynamics of barley grains. This is probably due to significant stimulation of the activity of lytic enzymes that cleave the storage substances in the aleurone layers and in the starch endosperm. Slight stimulation of antioxidant enzyme activity improves the detoxification of emerging reactive oxygen species, leading to better production parameters and an overall improvement in the vitality of young barley seedlings. However, reactive oxygen species generated during plasma treatment could have negative effects on DNA molecules, as was proved in our study. Therefore, cold atmospheric pressure plasma application can represent a new green technology for the improvement of surface decontamination and germination of various seeds and grains, but its potentially harmful effects need to be further investigated.

Author Contributions: Conceptualization, R.Š., S.K., L'.S. and E.G.; methodology, R.Š., S.K., L'.S. and V.M.; validation, M.P., R.Š., S.K. and L'.S.; formal analysis, M.P., R.Š. and S.K.; investigation, M.P., R.Š., S.K. and V.M.; resources, V.M., L'S. and E.G.; data curation, M.P., R.Š., S.K. and L'.S.; writing—original draft preparation, M.P., R.Š., S.K., V.M. and L'S.; writing—review and editing, V.M., L'S., A.Š. and E.G.; visualization, M.P., R.Š., S.K., V.M. and L'S.; supervision, L'.S., A.Š. and E.G.; project administration, R.Š. and S.K.; funding acquisition, E.G. All authors have read and agreed to the published version of the manuscript.

Funding: This research was funded by the Slovak Research and Development Agency, grant APVV16-0216, and by project VEGA 1/0410/18.

Institutional Review Board Statement: Not applicable.

Informed Consent Statement: Not applicable.

Acknowledgments: We would like to thank Anna Zahoranová and Eva Miadoková for their supervision and assistance during manuscript preparation. Our thanks also go to Mgr. Ján Renčko for his assistance in the experiments.

Conflicts of Interest: The authors declare no conflict of interest.

\section{References}

1. Ekanayake, U.M.; Seo, D.H.; Faershteyn, K.; O’Mullane, A.P.; Shon, H.; MacLeod, J.; Golberg, D.; Ostrikov, K. Atmosphericpressure plasma seawater desalination: Clean energy, agriculture, and resource recovery nexus for a blue planet. Sustain. Mater. Technol. 2020, 25, e00181. [CrossRef]

2. Lee, M.; Fan, C.-S.; Chen, Y.-W.; Chang, K.-C.; Chiueh, P.-T.; Hou, C.-H. Membrane capacitive deionization for low-salinity desalination in the reclamation of domestic wastewater effluents. Chemosphere 2019, 235, 413-422. [CrossRef]

3. Zhang, Q.; Ma, R.; Tian, Y.; Su, B.; Wang, K.; Yu, S.; Zhang, J.; Fang, J. Sterilization Efficiency of a Novel Electrochemical Disinfectant against Staphylococcus aureus. Environ. Sci. Technol. 2016, 50, 3184-3192. [CrossRef]

4. Wang, T.C.; Qu, G.; Li, J.; Liang, D.; Hu, S. Depth dependence of p-nitrophenol removal in soil by pulsed discharge plasma. Chem. Eng. J. 2014, 239, 178-184. [CrossRef] 
5. Stryczewska, H.D.; Pawłat, J.; Ebihara, K. Non-Thermal Plasma Aided Soil Decontamination. J. Adv. Oxid. Technol. 2016, 16. [CrossRef]

6. Štěpánová, V.; Slavíček, P.; Kelar, J.; Prášil, J.; Smékal, M.; Stupavská, M.; Jurmanová, J.; Černák, M. Atmospheric pressure plasma treatment of agricultural seeds of cucumber (Cucumis sativus L.) and pepper (Capsicum annuum L.) with effect on reduction of diseases and germination improvement. Plasma Process. Polym. 2017, 15, 1-9. [CrossRef]

7. Abedi, S.; Iranbakhsh, A.; Ardebili, Z.O.; Ebadi, M. Seed priming with cold plasma improved early growth, flowering, and protection of Cichorium intybus against selenium nanoparticle. J. Theor. Appl. Phys. 2020, 14, 113-119. [CrossRef]

8. Ma, R.; Wang, G.; Tian, Y.; Wang, K.; Zhang, J.; Fang, J. Non-thermal plasma-activated water inactivation of food-borne pathogen on fresh produce. J. Hazard. Mater. 2015, 300, 643-651. [CrossRef]

9. Guo, J.; Huang, K.; Wang, X.; Lyu, C.; Yang, N.; Li, Y.; Wang, J. Inactivation of Yeast on Grapes by Plasma-Activated Water and Its Effects on Quality Attributes. J. Food Prot. 2017, 80, 225-230. [CrossRef] [PubMed]

10. Muhammad, A.I.; Chen, W.; Liao, X.; Xiang, Q.; Liu, D.; Ye, X.; Ding, T. Effects of Plasma-Activated Water and Blanching on Microbial and Physicochemical Properties of Tiger Nuts. Food Bioprocess Technol. 2019, 12, 1721-1732. [CrossRef]

11. Ghorashi, A.H.; Tasouji, M.A.R.; Kargarian, A. Optimum cold plasma generating device for treatment of Aspergillus flavus from nuts surface. J. Food Sci. Technol. 2020, 57, 3988-3994. [CrossRef]

12. Hertwig, C.; Leslie, A.; Meneses, N.; Reineke, K.; Rauh, C.; Schlüter, O. Inactivation of Salmonella Enteritidis PT30 on the surface of unpeeled almonds by cold plasma. Innov. Food Sci. Emerg. Technol. 2017, 44, 242-248. [CrossRef]

13. Šerá, B.; Šerý, M. Non-thermal plasma treatment as a new biotechnology in relation to seeds, dry fruits, and grains. Plasma Sci. Technol. 2018, 20, 044012. [CrossRef]

14. Butscher, D.; Van Loon, H.; Waskow, A.; von Rohr, P.R.; Schuppler, M. Plasma inactivation of microorganisms on sprout seeds in a dielectric barrier discharge. Int. J. Food Microbiol. 2016, 238, 222-232. [CrossRef]

15. Koga, K.; Thapanut, S.; Amano, T.; Seo, H.; Itagaki, N.; Hayashi, N.; Shiratani, M. Simple method of improving harvest by nonthermal air plasma irradiation of seeds of Arabidopsis thaliana (L.). Appl. Phys. Express 2016, 9, 016201. [CrossRef]

16. Stolárik, T.; Henselová, M.; Martinka, M.; Novák, O.; Zahoranová, A.; Černák, M. Effect of Low-Temperature Plasma on the Structure of Seeds, Growth and Metabolism of Endogenous Phytohormones in Pea (Pisum sativum L.). Plasma Chem. Plasma Process. 2015, 35, 659-676. [CrossRef]

17. Zahoranová, A.; Hoppanová, L.; Šimončicová, J.; Tučeková, Z.; Medvecká, V.; Hudecová, D.; Kaliňáková, B.; Kováčik, D.; Černák, M. Effect of Cold Atmospheric Pressure Plasma on Maize Seeds: Enhancement of Seedlings Growth and Surface Microorganisms Inactivation. Plasma Chem. Plasma Process. 2018, 38, 969-988. [CrossRef]

18. Selcuk, M.; Oksuz, L.; Basaran, P. Decontamination of grains and legumes infected with Aspergillus spp. and Penicillum spp. by cold plasma treatment. Bioresour. Technol. 2008, 99, 5104-5109. [CrossRef] [PubMed]

19. Waskow, A.; Betschart, J.; Butscher, D.; Oberbossel, G.; Klöti, D.; Büttner-Mainik, A.; Adamcik, J.; Von Rohr, P.R.; Schuppler, M. Characterization of Efficiency and Mechanisms of Cold Atmospheric Pressure Plasma Decontamination of Seeds for Sprout Production. Front. Microbiol. 2018, 9, 3164. [CrossRef] [PubMed]

20. Leymarie, J.; Vitkauskaité, G.; Hoang, H.H.; Gendreau, E.; Chazoule, V.; Meimoun, P.; Corbineau, F.; El-Maarouf-Bouteau, H.; Bailly, C. Role of Reactive Oxygen Species in the Regulation of Arabidopsis Seed Dormancy. Plant. Cell Physiol. 2012, 53, 96-106. [CrossRef] [PubMed]

21. Liu, Y.; Ye, N.; Liu, R.; Chen, M.; Zhang, J. $\mathrm{H}_{2} \mathrm{O}_{2}$ mediates the regulation of ABA catabolism and GA biosynthesis in Arabidopsis seed dormancy and germination. J. Exp. Bot. 2010, 61, 2979-2990. [CrossRef]

22. Filatova, I.; Azharonok, V.; Kadyrov, M.; Beljavsky, V.; Gvozdov, A.; Shik, A.; Antonuk, A. The effect of plasma treatment of seeds of some grain and legumes on their sowing quality and productivity. Rom. J. Phys. 2011, 56, 139-143.

23. Bormashenko, E.; Grynyov, R.; Bormashenko, Y.; Drori, E. Cold Radiofrequency Plasma Treatment Modifies Wettability and Germination Speed of Plant Seeds. Sci. Rep. 2012, 2, 741. [CrossRef]

24. Wannicke, N.; Wagner, R.; Stachowiak, J.; Nishime, T.M.C.; Ehlbeck, J.; Weltmann, K.; Brust, H. Efficiency of plasma-processed air for biological decontamination of crop seeds on the premise of unimpaired seed germination. Plasma Process. Polym. 2021, 18, 1-14. [CrossRef]

25. Molina, R.; López-Santos, C.; Gómez-Ramírez, A.; Vílchez, A.; Espinós, J.P.; González-Elipe, A.R. Influence of irrigation conditions in the germination of plasma treated Nasturtium seeds. Sci. Rep. 2018, 8, 1-11. [CrossRef]

26. Abdul-Baki, A.A.; Anderson, J.D. Vigor Determination in Soybean Seed by Multiple Criteria 1. Crop. Sci. 1973, 13, 630-633. [CrossRef]

27. Bradford, M.M. A rapid and sensitive method for the quantitation of microgram quantities of protein utilizing the principle of protein-Dye binding. Anal. Biochem. 1976, 72, 248-254. [CrossRef]

28. Volin, J.C.; Denes, F.S.; Young, R.A.; Park, S.M.T. Modification of Seed Germination Performance through Cold Plasma Chemistry Technology. Crop. Sci. 2000, 40, 1706-1718. [CrossRef]

29. Meng, Y.; Qu, G.; Wang, T.; Sun, Q.; Liang, D.; Hu, S. Enhancement of Germination and Seedling Growth of Wheat Seed Using Dielectric Barrier Discharge Plasma with Various Gas Sources. Plasma Chem. Plasma Process. 2017, 37, 1105-1119. [CrossRef]

30. Sera, B.; Spatenka, P.; Sery, M.; Vrchotova, N.; Hruskova, I. Influence of Plasma Treatment on Wheat and Oat Germination and Early Growth. IEEE Trans. Plasma Sci. 2010, 38, 2963-2968. [CrossRef] 
31. Meiqiang, Y.; Mingjing, H.; Buzhou, M.; Tengcai, M. Stimulating Effects of Seed Treatment by Magnetized Plasma on Tomato Growth and Yield. Plasma Sci. Technol. 2005, 7, 3143-3147. [CrossRef]

32. Park, Y.; Oh, K.S.; Oh, J.; Seok, D.C.; Kim, S.B.; Yoo, S.J.; Lee, M. The biological effects of surface dielectric barrier discharge on seed germination and plant growth with barley. Plasma Process. Polym. 2018, 15, e1600056. [CrossRef]

33. Szőke, C.; Nagy, Z.; Gierczik, K.; Székely, A.; Spitkól, T.; Zsuboril, Z.T.; Galiba, G.; Marton, C.L.; Kutasi, K. Effect of the afterglows of low pressure $\mathrm{Ar} / \mathrm{N}_{2}-\mathrm{O}_{2}$ surface-wave microwave discharges on barley and maize seeds. Plasma Process. Polym. 2018, 15, 1700138. [CrossRef]

34. Henselová, M.; Slováková, L'.; Martinka, M.; Zahoranová, A. Growth, anatomy and enzyme activity changes in maize roots induced by treatment of seeds with low-temperature plasma. Biologia 2012, 67, 490-497. [CrossRef]

35. Nishime, T.M.C.; Wannicke, N.; Horn, S.; Weltmann, K.-D.; Brust, H. A Coaxial Dielectric Barrier Discharge Reactor for Treatment of Winter Wheat Seeds. Appl. Sci. 2020, 10, 7133. [CrossRef]

36. Chen, H.H.; Chen, Y.K.; Chang, H.C. Evaluation of physicochemical properties of plasma treated brown rice. Food Chem. 2012, 135, 74-79. [CrossRef]

37. Šerá, B.; Sery, M.; Stranak, V.; Spatenka, P.; Tichy, M. Does Cold Plasma Affect Breaking Dormancy and Seed Germination? A Study on Seeds of Lamb's Quarters (Chenopodium album agg.). Plasma Sci. Technol. 2009, 11, 750-754. [CrossRef]

38. Švubová, R.; Kyzek, S.; Medvecká, V.; Slováková, L'.; Gálová, E.; Zahoranová, A. Novel insight at the Effect of Cold Atmospheric Pressure Plasma on the Activity of Enzymes Essential for the Germination of Pea (Pisum sativum L. cv. Prophet) Seeds. Plasma Chem. Plasma Process. 2020, 40, 1221-1240. [CrossRef]

39. Li, L.; Jiang, J.F.; Li, J.; Shen, M.; He, X.; Shao, H.; Dong, Y. Effects of cold plasma treatment on seed germination and seedling growth of soybean. Sci. Rep. 2015, 4, srep05859. [CrossRef]

40. Švubová, R.; Slováková, L'.; Holubová, L'.; Rovňanová, D.; Gálová, E.; Tomeková, J. Evaluation of the Impact of Cold Atmospheric Pressure Plasma on Soybean Seed Germination. Plants 2021, 10, 177. [CrossRef]

41. Kyzek, S.; Holubová, L'; Medvecká, V.; Tomeková, J.; Gálová, E.; Zahoranová, A. Cold Atmospheric Pressure Plasma Can Induce Adaptive Response in Pea Seeds. Plasma Chem. Plasma Process. 2018, 39, 475-486. [CrossRef]

42. Tomeková, J.; Kyzek, S.; Medvecká, V.; Gálová, E.; Zahoranová, A. Influence of Cold Atmospheric Pressure Plasma on Pea Seeds: DNA Damage of Seedlings and Optical Diagnostics of Plasma. Plasma Chem. Plasma Process. 2020, 40, 1-14. [CrossRef]

43. Sang, T. Genes and Mutations Underlying Domestication Transitions in Grasses: Figure 1. Plant. Physiol. 2009, 149, 63-70. [CrossRef]

44. Lepiniec, L.; Debeaujon, I.; Routaboul, J.-M.; Baudry, A.; Pourcel, L.; Nesi, N.; Caboche, M. Genetics and biochemistry of seed flavonoids. Annu. Rev. Plant. Biol. 2006, 57, 405-430. [CrossRef]

45. Yang, L.; Xian, D.; Xiong, X.; Lai, R.; Song, J.; Zhong, J. Proanthocyanidins against Oxidative Stress: From Molecular Mechanisms to Clinical Applications. BioMed Res. Int. 2018, 2018, 1-11. [CrossRef]

46. Dubinov, A.; Lazarenko, E.; Selemir, V. Effect of glow discharge air plasma on grain crops seed. IEEE Trans. Plasma Sci. 2000, 28, 180-183. [CrossRef]

47. Masoni, A.; Pampana, S.; Arduini, I. Barley Response to Waterlogging Duration at Tillering. Crop. Sci. 2016, 56, 2722-2730. [CrossRef]

48. Olsen, O.-A. ENDOSPERM DEVELOPMENT: Cellularization and Cell Fate Specification. Annu. Rev. Plant. Biol. 2001, 52, $233-267$. [CrossRef] [PubMed]

49. Olsen, O.-A. Nuclear Endosperm Development in Cereals and Arabidopsis thaliana. Plant. Cell 2004, 16, S214-S227. [CrossRef]

50. Chrispeels, M.J.; Varner, J.E. Gibberellic Acid-Enhanced Synthesis and Release of $\alpha$-Amylase and Ribonuclease by Isolated Barley and Aleurone Layers. Plant. Physiol. 1967, 42, 398-406. [CrossRef] [PubMed]

51. McCrate, A.J.; Nielsen, M.T.; Paulsen, G.M.; Heyne, E.G. Gibberellic acid effects on germination and $\alpha$-amylase activity of winter wheats. Euphytica 1981, 30, 875-880. [CrossRef]

52. Joshi, R. Role of enzymes in seed germination. Int. J. Creat. Res. Thoughts 2018, 6, 1481-1485.

53. Los, A.; Ziuzina, D.; Boehm, D.; Cullen, P.J.; Bourke, P. Investigation of mechanisms involved in germination enhancement of wheat (Triticum aestivum) by cold plasma: Effects on seed surface chemistry and characteristics. Plasma Process. Polym. 2019, 16. [CrossRef]

54. Yemeli, G.B.N.; Švubová, R.; Kostolani, D.; Kyzek, S.; Machala, Z. The effect of water activated by nonthermal air plasma on the growth of farm plants: Case of maize and barley. Plasma Process. Polym. 2021, 18. [CrossRef]

55. O'Connell, D.; Cox, L.J.; Hyland, W.B.; McMahon, S.J.; Reuter, S.; Graham, W.G.; Gans, T.; Currell, F.J. Cold atmospheric pressure plasma jet interactions with plasmid DNA. Appl. Phys. Lett. 2011, 98, 043701. [CrossRef]

56. Alkawareek, M.Y.; Alshraiedeh, N.H.; Higginbotham, S.; Flynn, P.B.; Algwari, Q.T.; Gorman, S.P.; Graham, W.G.; Gilmore, B.F. Plasmid DNA Damage Following Exposure to Atmospheric Pressure Nonthermal Plasma: Kinetics and Influence of Oxygen Admixture. Plasma Med. 2014, 4, 211-219. [CrossRef]

57. Lee, G.J.; Choi, M.A.; Kim, D.; Kim, J.Y.; Ghimire, B.; Choi, E.H.; Kim, S.H. Influence of plasma-generated reactive species on the plasmid DNA structure and plasmid-mediated transformation of Escherichia coli cells. J. Appl. Phys. 2017, 122, 103303. [CrossRef]

58. Arjunan, K.P.; Sharma, V.K.; Ptasinska, S. Effects of Atmospheric Pressure Plasmas on Isolated and Cellular DNA-A Review. Int. J. Mol. Sci. 2015, 16, 2971-3016. [CrossRef] 
59. Tendero, C.; Tixier, C.; Tristant, P.; Desmaison, J.; Leprince, P. Atmospheric pressure plasmas: A review. Spectrochim. Acta Part B At. Spectrosc. 2006, 61, 2-30. [CrossRef]

60. Ehlbeck, J.; Schnabel, U.; Polak, M.; Winter, J.; Von Woedtke, T.; Brandenburg, R.; von dem Hagen, T.; Weltmann, K.-D. Low temperature atmospheric pressure plasma sources for microbial decontamination. J. Phys. D Appl. Phys. 2011, $44,013002$. [CrossRef]

61. Setsuhara, Y. Low-temperature atmospheric-pressure plasma sources for plasma medicine. Arch. Biochem. Biophys. 2016, 605, 3-10. [CrossRef] [PubMed]

62. Černák, M.; Černáková, L.; Hudec, I.; Kováčik, D.; Zahoranová, A. Diffuse Coplanar Surface Barrier Discharge and its applications for in-line processing of low-added-value materials. Eur. Phys. J. Appl. Phys. 2009, 47, 22806. [CrossRef]

63. Mošovská, S.; Medvecká, V.; Gregová, M.; Tomeková, J.; Valík, L'.; Mikulajová, A.; Zahoranová, A. Plasma inactivation of Aspergillus flavus on hazelnut surface in a diffuse barrier discharge using different working gases. Food Control. 2019, 104, 256-261. [CrossRef]

64. Matusikova, V.; Salaj, J.; Moravčíková, J.; Mlynárová, L.; Nap, J.-P.; Libantová, J. Tentacles of in vitro-grown round-leaf sundew (Drosera rotundifolia L.) show induction of chitinase activity upon mimicking the presence of prey. Planta 2005, 222, 1020-1027. [CrossRef]

65. Somogyi, M. Notes on sugar determination. J. Biol. Chem. 1952, 195, 19-23. [CrossRef]

66. Nelson, N. A photometric adaptation of the Somogyi method for determination of glucose. J. Biol. Chem. 1944, 153, 375-380. [CrossRef]

67. Frič, F.; Fuchs, W.H. Veränderungen der Aktivität einiger Enzyme im Weizenblatt in Abhängigkeit von der temperaturlabilen Verträglichkeit für Puccinia graminis tritici. J. Phytopathol. 1970, 67, 161-174. [CrossRef]

68. Beauchamp, C.; Fridovich, I. Superoxide dismutase: Improved assays and an assay applicable to acrylamide gels. Anal. Biochem. 1971, 44, 276-287. [CrossRef]

69. Hartmann, A. Recommendations for conducting the in vivo alkaline Comet assay. Mutagenesis 2003, 18, 45-51. [CrossRef]

70. Collins, A.R. The Comet Assay for DNA Damage and Repair: Principles, Applications, and Limitations. Mol. Biotechnol. 2004, 26, 249-261. [CrossRef]

71. Gichner, T.; Patková, Z.; Száková, J.; Žnidar, I.; Mukherjee, A. DNA damage in potato plants induced by cadmium, ethyl methanesulphonate and $\gamma$-rays. Environ. Exp. Bot. 2008, 62, 113-119. [CrossRef]

72. Collins, A.R. Measuring oxidative damage to DNA and its repair with the comet assay. Biochim. Biophys. Acta (BBA)—Gen. Subj. 2014, 1840, 794-800. [CrossRef]

73. Chankova, S.G.; Bryant, P.E. Acceleration of DNA-double strand rejoining during the adaptive response of Chlamydomonas reinhardtii. Radiat. Biol. Radioecol. 2002, 42, 600-603.

74. Muslimović, A.; Nyström, S.; Gao, Y.; Hammarsten, O. Numerical Analysis of Etoposide Induced DNA Breaks. PLoS ONE 2009, 4, e5859. [CrossRef] 